\title{
Assessment of Ground Water Quality By Using Water Quality Index Method of Berhampur Town In Odisha, India
}

\author{
BIJAYA KUMAR GOUDA ${ }^{1}$, EJAZ AHMED ${ }^{2 *}$ and MUKUNDA KESARI KHADANGA ${ }^{3}$ \\ ${ }^{1}$ Department of Chemistry, Science College, Hinjilicut, Ganjam - 761102, Odisha, India. \\ ${ }^{2} \mathrm{Head}$ of the Department of Chemistry, M.M. Mahavidyalaya, \\ Berhampur-760001, Ganjam, Odisha, India. \\ ${ }^{3}$ Project Scientist, NIOT, Chennai-600100, India.
}

http://dx.doi.org/10.12944/CWE.9.3.49

(Received: April 01, 2014; Accepted: October 09, 2014)

\begin{abstract}
Berhampur, the silk city of Odisha (India) is under the process of rapid urbanization with human population exceeding more than four lacks. Such growth in population of Berhampur Municipal Corporation has increased the requirement of water for human activities. Due to this reason the huge amount of waste water is generated which is discharged to the Bay of Bengal through small sewage system. The present study is carried out the impact of ground water quality status of Berhampur town. The water samples collected from ten different locations have been chosen separately across Berhampur Municipal Corporation depending on pollution load and water logging. The samples were collected in three different seasons i.e monsoon (MN, June-September), post monsoon (PM, November-January) and pre monsoon (PRM, March-May) and to determine the physical, chemical and biological parameters. The WQI reflects a composite influence of contributing factors on the quality of water for any type of water system. So WQI is an important parameter for assessment and management of ground water. Now a day's water quality of different water system has been communicated on the basis of calculated WQI. The presents study revels that water quality index is 1 to 10 sampling station (S-1, S-2, S-4, S-5, S-6, S-7, S-8) come under good water quality and station (S-3, S-9, S-10) belongs to poor water. This may be due the sewage water logging in those study area which will definitely put serious impact up on socio-economic development of the people in this area in future.
\end{abstract}

Key words: Ground water, Water Quality Parameters, Water Quality Index.

\section{INTRODUCTION}

Berhampur, one of the largest city of Odisha nick name silk city is located in eastern coast line of Ganjam district, Odisha, India. It is situated in between 19ú58'E Latitude and 84Ú5'”N Longitude. The city is grown into Municipal Corporation which consists of 40 wards and population of about four lacks. This city is situated about $15 \mathrm{~km}$ away from Bay of Bengal which makes the city condition extremely humid. The maximum temperature during summer season $40^{\circ} \mathrm{C}$, whereas minimum temperature reaches to $22^{\circ} \mathrm{C}$-during winter season. The city experiences average annual rain fall of $1250 \mathrm{~mm}$ with the set of south west monsoon.
On account of rapid urbanization there has been a rapid growth in huge building, apartment, hotel, hospital, technical institute, transportation and vehicles. This leads to the increase in requirement of water for domestic purpose as well as drinking purposes. The river Rusikulya is the major distributing river for water supply as well as Dakhinapur reservoir is the second source of water for Berhampur city. This water supply is insufficient for the total pollution for which about $55 \%$ human population depends on ground water. But the ground water is getting polluted due to various human activities and water logging of waste water from the houses due to improper sewage system for which ground water is contaminated due to seepage from effluent bearing 
water body (Adekunle, 2009). Over burden of the population pressure unplanned urbanization on restricted exploration and dumping of the polluted water at in appropriate place enhance infiltration of harmful compounds to the ground water (Pandey and Tiwari, 2009).

In view of this it is imperative to analyse the ground water quality in order to know the level of pollution, so that appropriate measures could be taken to over come the pollution problem and make the ground water pollution free or pollution minimized.

\section{MATERIAL AND METHOD}

Only tube wells were selected from ten sampling points Table 1. The grab samples were

Table. 1: Location of point of ground water in Berhampur town

STNo Code No Location of sampling
point

\begin{tabular}{lll}
1 & S1 & Khodasing (TW) \\
2 & S2 & Industrial Estate(TW) \\
3 & S3 & M.K.C.G. Medical(TW) \\
4 & S4 & New Bustand(TW) \\
5 & S5 & Old Bustand(TW) \\
6 & S6 & Gandhi Nagar(TW) \\
7 & S7 & Gate Bazar(TW) \\
8 & S8 & Radio Station(TW) \\
9 & S9 & Haradakhandi(TW) \\
10 & S10 & Rail way station (TW) \\
\hline
\end{tabular}

collected in plastic and glass bottles as per the requirement. The sampling was done during June 11 to May 12 on three monsoon seasons .Different physical, chemical and biological parameters such as $\mathrm{pH}$, turbidity, E-conductivity, total alkalinity, $\mathrm{TH}$, TDS, Iron, $\mathrm{Cl}, \mathrm{NO}_{3}$; Calcium and magnesium were analyzed in laboratory as per following procedure in Table-2. All chemicals and reagents used for the analysis were of analytical reagent grade (Patel and Sing, 1998),(Trivedy and Goel,1984).

\section{Water quality Index (WQI)}

For computing WQI three steps are followed. In the first step each of the parameters has been assigned a weight according to its relative importance in the overall quality of water for drinking purpose (Table.3). The maximum weight of 5 has been assigned to the parameter $\mathrm{NO}_{3}{ }^{-1}$ due to its major importance in water quality assessment. Magnesium which is given the minimum weight of 1 , as magnesium by itself may not be harmful to other. In the second step, the relative weight $\left(w_{i}\right)$ is computed from the following equation:

$$
W_{i=} W_{i} / \Sigma_{i=1}{ }^{n} W_{i}
$$

where $W_{1}$ is the relative weight $w_{i}$ is the weight each parameter and $n$ is the number of parameter calculated relative weight $\left(\mathrm{W}_{\mathrm{i}}\right)$ values of each parameter are also given in Table- 04. In third step a quality, rating scale (qi) for each parameter is assigned by dividing its concentration in each water sample by its respective standard according to the guidelines in the WHO and the result multiplied by 100.

Table. 2: Methods of analysis of different parameters

\begin{tabular}{llll}
\hline SI. No & Parameters & Unit & Method of Analysis \\
\hline 1 & pH value & & $\mathrm{pH}$ meter \\
2 & Turbidity & $\mathrm{NTU}$ & Nephlo turbidity \\
3 & TDS & $\mathrm{mg} / \mathrm{l}$ & Gravimetric method \\
4 & $\mathrm{E} . \mathrm{C}$ & $\mathrm{MS} / \mathrm{cm}$ & Conductivity meter \\
5 & $\mathrm{TH}$ & $\mathrm{mg} / \mathrm{l}$ & Titrimetricmethod(EDTA) \\
6 & $\mathrm{Alkalinity}$ & $\mathrm{mg} / \mathrm{l}$ & Titration with $\mathrm{H}_{2} \mathrm{SO}_{4}$ \\
7 & $\mathrm{Ca}^{2+}$ & $\mathrm{mg} / \mathrm{l}$ & EDTA Titration \\
8 & $\mathrm{Mg}^{2+}$ & $\mathrm{mg} / \mathrm{l}$ & EDTA Titration \\
9 & $\mathrm{Cl}^{-}$ & $\mathrm{mg} / \mathrm{l}$ & AgNO ${ }_{3}$ Argentometrictitration \\
10 & $\mathrm{NO}_{3}-$ & $\mathrm{mg} / \mathrm{l}$ & UV screening \\
\hline
\end{tabular}




$$
\mathrm{Qi}=(\mathrm{ci} / \mathrm{Si}) \times 100
$$

Where qi is the quality rating, $\mathrm{Ci}$ is the concentration each chemical parameter on each water sample in $\mathrm{mg} / \mathrm{l}, \mathrm{Si}$ is the Indian drinking water standard for each chemical parameter in $\mathrm{mg} / \mathrm{l}$ according to guideline of the BIS $-10500,1991$. Forth computing the WQI the first is determined the each chemical parameter which is used then the WQI as per the following equation,

$$
\begin{aligned}
& S i=W I \times \text { qi } \\
& W Q I=\Sigma S i
\end{aligned}
$$

$\mathrm{Si}$ is the sub index of ten parameter, qi is the rating base on concentration of the ten parameter , and $\mathrm{n}$ is the number of the parameter.The computed WQI values are classified in to four types Excellent

Table. 3: Water quality classification based in WQI value

\begin{tabular}{lc}
\hline WQI & Water quality \\
\hline$<50$ & Excellent \\
$50-100$ & Good \\
$100-200$ & Poor \\
$200-300$ & Very Poor \\
\hline
\end{tabular}

Table. 4: Relative values of chemical parameter

\begin{tabular}{lccc}
\hline Parameter & $\begin{array}{c}\text { Highest permitted } \\
\text { value for water } \\
\text { with reference } \\
\text { to WHO standards }\end{array}$ & $\begin{array}{c}\text { Weight } \\
\left.\mathbf{( w}_{\mathbf{i}}\right)\end{array}$ & $\begin{array}{c}\text { Relative } \\
\text { weight(Wi) }\end{array}$ \\
\hline $\mathrm{PH}$ & $7.0-8.5$ & 4 & 0.1379 \\
Turbidity & 5 & 4 & 0.1379 \\
TDS & 500 & 4 & 0.1379 \\
TH & 300 & 2 & 0.689 \\
$\mathrm{Alkalinity}_{\mathrm{Ca}}^{2+}$ & 900 & 3 & 0.1034 \\
$\mathrm{Mg}^{2+}$ & 75 & 2 & 0.689 \\
$\mathrm{Cl}^{-1}$ & 50 & 2 & 0.689 \\
$\mathrm{No}_{3}^{-1}$ & 200 & 3 & 0.134 \\
& 50 & 5 & 0.1724 \\
\hline
\end{tabular}

Table. 5: Seasonal variation of $\mathrm{pH}$ value with average and permissible value

\begin{tabular}{ccccccc}
\hline $\begin{array}{c}\text { SI. } \\
\text { No }\end{array}$ & $\begin{array}{c}\text { Location } \\
\text { Points }\end{array}$ & $\begin{array}{c}\text { Mon } \\
\text { soon }\end{array}$ & $\begin{array}{c}\text { Post } \\
\text { monsoon }\end{array}$ & $\begin{array}{c}\text { Pre } \\
\text { monsoon }\end{array}$ & Average & $\begin{array}{c}\text { Remarks: } \\
\text { Permissible value } \\
\text { with reference to } \\
\text { WHO (7.0 to 8.5) }\end{array}$ \\
\hline 1 & S1 & 7.2 & 7.1 & 7.1 & 7.13 & Permissible \\
2 & S2 & 7.3 & 6.9 & 7.0 & 7.06 & Permissible \\
3 & S3 & 7.4 & 7.3 & 7.1 & 7.26 & permissible \\
4 & S4 & 7.3 & 7.1 & 7.0 & 7.13 & permissible \\
5 & S5 & 7.5 & 7.1 & 7.0 & 7.20 & permissible \\
6 & S6 & 7.4 & 7.2 & 7.1 & 7.23 & permissible \\
7 & S7 & 7.4 & 7.3 & 7.1 & 7.26 & permissible \\
8 & S8 & 7.6 & 7.2 & 7.2 & 7.33 & permissible \\
9 & S9 & 7.8 & 7.2 & 7.2 & 7.40 & permissible \\
10 & S10 & 7.6 & 7.3 & 7.3 & 7.40 & permissible \\
\hline
\end{tabular}


water to, unsuitable for the drinking.

\section{RESULT AND DISCUSSION}

The result of different parameter compered individually by taking data of pre monsoon, monsoon $\&$ post monsoon seasons which are reflected in table 05 to 14 and in figure 2 .

pH

Maximum $\mathrm{pH}$ observed at sample station
S-9 i.e. 7.8 and minimum was observed at sample station $\mathrm{S}-2$ is 6.9 . The $\mathrm{pH}$ range in all the station is with in permissible limit i.e. 07 to 8.5 (WHO) standard.

\section{Turbidity}

Maximum turbidity was observed at sample station S-5 is 16.2 and minimum was observed at sample station S-7 is 9.5 NTU. The result revels that the turbidity range all the station is above the desirable limit value i.e. 5 (NTU) in drinking water (WHO) standard. This may attributed to the pressure

Table. 6: Seasonal variation of turbidity (NTU) value with average and permissible value

\begin{tabular}{lcccccc}
\hline $\begin{array}{c}\text { SI. } \\
\text { No }\end{array}$ & $\begin{array}{c}\text { Location } \\
\text { Points }\end{array}$ & $\begin{array}{c}\text { Mon } \\
\text { soon }\end{array}$ & $\begin{array}{c}\text { Post } \\
\text { monsoon }\end{array}$ & $\begin{array}{c}\text { Pre } \\
\text { monsoon }\end{array}$ & Average & $\begin{array}{c}\text { Remarks: } \\
\text { Permissible value } \\
\text { with reference to } \\
\text { WHO (5.0NTU) }\end{array}$ \\
\hline 1 & S1 & 10.9 & 12.9 & 13.9 & 12.56 & Excessive \\
2 & S2 & 11.8 & 12.4 & 14.8 & 13.0 & Excessive \\
3 & S3 & 10.5 & 11.3 & 15.4 & 12.4 & Excessive \\
4 & S4 & 10.5 & 11.4 & 14.7 & 12.2 & Excessive \\
5 & S5 & 10.3 & 12.3 & 16.2 & 12.93 & Excessive \\
6 & S6 & 10.2 & 12.2 & 15.8 & 12.73 & Excessive \\
7 & S7 & 9.5 & 11.3 & 14.7 & 11.83 & Excessive \\
8 & S8 & 10.2 & 11.9 & 15.2 & 12.43 & Excessive \\
9 & S9 & 9.5 & 12.4 & 14.9 & 12.26 & Excessive \\
10 & S10 & 10.2 & 13.3 & 15.4 & 12.96 & Excessive \\
\hline
\end{tabular}

Table. 7: Seasonal variation of Total dissolved solid (TDS) $\mathrm{mg} / \mathrm{l}$ value with average and permissible value

\begin{tabular}{lcccccc}
\hline $\begin{array}{c}\text { SI. } \\
\text { No }\end{array}$ & $\begin{array}{c}\text { Location } \\
\text { Points }\end{array}$ & $\begin{array}{c}\text { Mon } \\
\text { soon }\end{array}$ & $\begin{array}{c}\text { Post } \\
\text { monsoon monsoon }\end{array}$ & $\begin{array}{c}\text { Pre } \\
\text { Average }\end{array}$ & $\begin{array}{c}\text { Remarks: } \\
\text { Permissible value } \\
\text { with reference to } \\
\text { WHO (500mg/l) }\end{array}$ \\
\hline & & & & & & \\
1 & S1 & 510 & 540 & 640 & 563.33 & Excessive \\
2 & S2 & 515 & 534 & 690 & 579.66 & Excessive \\
3 & S3 & 600 & 683 & 804 & 695.66 & Excessive \\
4 & S4 & 540 & 666 & 712 & 639.33 & Excessive \\
5 & S5 & 576 & 612 & 712 & 633.33 & Excessive \\
6 & S6 & 582 & 635 & 810 & 675.66 & Excessive \\
7 & S7 & 573 & 679 & 799 & 683.66 & Excessive \\
8 & S8 & 587 & 671 & 810 & 689.33 & Excessive \\
9 & S9 & 590 & 683 & 799 & 690.66 & Excessive \\
10 & S10 & 601 & 698 & 840 & 713.00 & Excessive \\
\hline
\end{tabular}


of $\mathrm{Ca}^{2+}$ and total Hardness (TH).

\section{TDS}

Maximum Total Dissolved Solid (TDS) was observed at sample station S-10 is $840 \mathrm{mg} / \mathrm{l}$ and minimum was observed at sample station $\mathrm{S}-1$ is 510 $\mathrm{mg} / \mathrm{l}$. The result revels that this value is excessive value for drinking water at the ten sample station i.e. $500 \mathrm{mg} / \mathrm{l}$ (WHO) standard. In water total dissolved solids are composed mainly Carbonate, bicarbonate, Magnesium, Salt and other particles.

\section{Electrical conductyvity}

Maximum E-Conductivity (EC) was observed at sample station S-10 i.e. $2.3 \mathrm{~ms} / \mathrm{cm}$ and minimum was observed at sample station $\mathrm{S}$ 1 i.e $1.1 \mathrm{~ms} / \mathrm{cm}$ (Fig. 2). The result revels that this value is within the range value for drinking water at the ten sample station i.e. 1.1 to $1.3 \mathrm{~ms} / \mathrm{cm}(\mathrm{WHO})$ standard.

\section{Total hardness (TH)}

Maximum Total Hardness (TH) was observed at sample station S-10 is $574 \mathrm{mg} / \mathrm{l}$ in pre monsoon season and minimum was observed at sample station S-3 is $295 \mathrm{mg} / \mathrm{l}$ in monsoon

Table. 8: Seasonal variation of Electrical conductivity (EC) MS/cm value with average and permissible value

\begin{tabular}{lcccccc}
\hline $\begin{array}{c}\text { SI. } \\
\text { No }\end{array}$ & $\begin{array}{c}\text { Location } \\
\text { Points }\end{array}$ & $\begin{array}{c}\text { Mon } \\
\text { soon }\end{array}$ & $\begin{array}{c}\text { Post } \\
\text { monsoon }\end{array}$ & $\begin{array}{c}\text { Pre } \\
\text { monsoon }\end{array}$ & Average & $\begin{array}{c}\text { Remarks: } \\
\text { Permissible value } \\
\text { with reference to } \\
\text { WHO (1.1-3.0 MS/cm) }\end{array}$ \\
\hline 1 & S1 & 1.1 & 1.3 & 1.2 & 1.2 & Permissible \\
2 & S2 & 1.2 & 1.4 & 1.2 & 1.26 & Permissible \\
3 & S3 & 1.7 & 1.9 & 1.6 & 1.73 & Permissible \\
4 & S4 & 1.6 & 1.7 & 1.5 & 1.6 & Permissible \\
5 & S5 & 1.5 & 1.7 & 1.6 & 1.6 & Permissible \\
6 & S6 & 1.4 & 1.7 & 1.3 & 1.46 & Permissible \\
7 & S7 & 1.5 & 1.5 & 1.2 & 1.4 & Permissible \\
8 & S8 & 1.4 & 1.8 & 1.3 & 1.5 & Permissible \\
9 & S9 & 1.9 & 1.9 & 1.5 & 1.7 & Permissible \\
10 & S10 & 2.0 & 2.3 & 1.9 & 2.1 & Permissible \\
\hline
\end{tabular}

Table. 9: Seasonal variation of Total Hard ness (TH) $\mathrm{mg} / \mathrm{l}$ value with average and permissible value

\begin{tabular}{lcccccc}
\hline $\begin{array}{c}\text { SI. } \\
\text { No }\end{array}$ & $\begin{array}{c}\text { Location } \\
\text { Points }\end{array}$ & $\begin{array}{c}\text { Mon } \\
\text { soon }\end{array}$ & $\begin{array}{c}\text { Post } \\
\text { monsoon }\end{array}$ & $\begin{array}{c}\text { Pre } \\
\text { monsoon }\end{array}$ & Average & $\begin{array}{c}\text { Remarks: } \\
\text { Permissible value } \\
\text { with reference to } \\
\text { WHO (300 mg/l ) }\end{array}$ \\
\hline 1 & S1 & 308 & 323 & 337 & 322.66 & Excessive \\
2 & S2 & 316 & 346 & 365 & 342.33 & Excessive \\
3 & S3 & 402 & 425 & 442 & 423.00 & Excessive \\
4 & S4 & 308 & 322 & 336 & 322.00 & Excessive \\
5 & S5 & 322 & 335 & 358 & 338.33 & Excessive \\
6 & S6 & 325 & 340 & 360 & 341.66 & Excessive \\
7 & S7 & 348 & 362 & 377 & 362.33 & Excessive \\
8 & S8 & 295 & 305 & 322 & 307.33 & Excessive \\
9 & S9 & 410 & 430 & 451 & 430.33 & Excessive \\
10 & S10 & 525 & 560 & 574 & 553.00 & Excessive \\
\hline
\end{tabular}


season(Fig. 2). The TH of all station has crossed the permissible limit i.e. $300 \mathrm{mg} / \mathrm{l}$ (WHO) standard. This value is more pronounced in pre monsoon season (Fig. 2). This may be due to nature accumulation of salt from contact with soil or it may enter from direct pollution by the human activity. This revels that the drinking water of such station for under hard water category.

Alkalinity

The alkalinity value seems to be highest in monsoon season at station S-9 is $850 \mathrm{mg} / \mathrm{l}$ at sample station and minimum at sample station $\mathrm{S}-7$ is $440 \mathrm{mg} / \mathrm{l}$ in post monsoon season. The high alkalinity value in the study is at sample station S-9 in monsoon season is due to increase in action of carbonate as the basic material in the soil, due to this reason the drinking water sample station of S-9 is unpleasant to taste.

$\mathrm{Cl}^{-}$

Maximum chloride was observed at sample station S-10 is $239 \mathrm{mg} / \mathrm{l}$ in post monsoon season and minimum was observed at sample station $S-1$ is

Fig. 10: Seasonal variation of Alkalinity $\mathrm{mg} / \mathrm{l}$ value with average and permissible value

\begin{tabular}{lcccccc}
\hline $\begin{array}{c}\text { SI. } \\
\text { No }\end{array}$ & $\begin{array}{c}\text { Location } \\
\text { Points }\end{array}$ & $\begin{array}{c}\text { Mon } \\
\text { soon }\end{array}$ & $\begin{array}{c}\text { Post } \\
\text { monsoon }\end{array}$ & $\begin{array}{c}\text { Pre } \\
\text { monsoon }\end{array}$ & Average & $\begin{array}{c}\text { Remarks: } \\
\text { Permissible value } \\
\text { with reference to } \\
\text { WHO (900 mg/l ) }\end{array}$ \\
\hline 1 & S1 & 652 & 630 & 615 & 632.33 & Permissible \\
2 & S2 & 702 & 690 & 670 & 687.33 & Permissible \\
3 & S3 & 590 & 540 & 525 & 551.667 & Permissible \\
4 & S4 & 680 & 530 & 510 & 573.33 & Permissible \\
5 & S5 & 648 & 634 & 522 & 601.33 & Permissible \\
6 & S6 & 705 & 659 & 634 & 666.00 & Permissible \\
7 & S7 & 680 & 440 & 510 & 543.33 & Permissible \\
8 & S8 & 710 & 670 & 642 & 674.00 & Permissible \\
9 & S9 & 850 & 740 & 620 & 736.66 & Permissible \\
10 & S10 & 600 & 530 & 511 & 547.00 & Permissible \\
\hline
\end{tabular}

Fig. 11: Seasonal variation of chloride $(\mathrm{Cl}-1) \mathrm{mg} / \mathrm{l}$ value with average and permissible value

\begin{tabular}{ccccccc}
\hline $\begin{array}{c}\text { SI. } \\
\text { No }\end{array}$ & $\begin{array}{c}\text { Location } \\
\text { Points }\end{array}$ & $\begin{array}{c}\text { Mon } \\
\text { soon }\end{array}$ & $\begin{array}{c}\text { Post } \\
\text { monsoon monsoon }\end{array}$ & $\begin{array}{c}\text { Pre } \\
\text { moverage }\end{array}$ & $\begin{array}{c}\text { Remarks: } \\
\text { Permissible value } \\
\text { with reference to } \\
\text { WHO (200 mg/l ) }\end{array}$ \\
\hline 1 & S1 & 98 & 105 & 110 & 104.33 & Permissible \\
2 & S2 & 105 & 125 & 127 & 119.00 & Permissible \\
3 & S3 & 220 & 215 & 217 & 217.33 & Excessive \\
4 & S4 & 115 & 124 & 125 & 121.33 & Permissible \\
5 & S5 & 118 & 127 & 127 & 124.00 & Permissible \\
6 & S6 & 106 & 121 & 121 & 116.00 & Permissible \\
7 & S7 & 118 & 127 & 130 & 125.00 & Permissible \\
8 & S8 & 129 & 139 & 140 & 136.00 & Permissible \\
9 & S9 & 225 & 218 & 216 & 219.66 & Excessive \\
10 & S10 & 230 & 239 & 236 & 235.00 & Excessive \\
\hline
\end{tabular}


$98 \mathrm{mg} / \mathrm{lin}$ monsoon season. The result shows that at station S-9 the $\mathrm{Cl}^{-}$value is also high. In this season the high amount of $\mathrm{Cl}^{-}$in ground water may be due to atmospheric precipitation, animal feeds, use of inorganic fertilizer and leaching process of the soil.

$\mathrm{Ca}^{2+}$

All the stations have high amount of $\mathrm{Ca}^{2+}$ ion present. High amount of calcium was found in the monsoon season, post monsoon, pre monsoon which is due to geological material aquifers which is composed of calcium mixed with ground water and is found in it suspension. Maximum calcium was observed at sample station S-7 is $180 \mathrm{mg} / \mathrm{l}$ in pre monsoon season (Fig. 2).

$\mathrm{Mg}^{2+}$

The magnesium values seems to be highest in monsoon season at the sample station S-10 is $295 \mathrm{mg} / \mathrm{l}$ and minimum at the sample station S-6 is $120 \mathrm{mg} / \mathrm{l}$ in pre monsoon season. The results revel that the values of magnesium range in all stations above the desirable limit value i.e $50 \mathrm{mg} / \mathrm{l}$ in drinking water (WHO) standard. This may be attributed to domestic waste, medical waste and also fall in water

Fig. 12: Seasonal variation of calcium (Ca2+) $\mathrm{mg} / \mathrm{l}$ value with average and permissible value

\begin{tabular}{lcccccc}
\hline $\begin{array}{c}\text { SI. } \\
\text { No }\end{array}$ & $\begin{array}{c}\text { Location } \\
\text { Points }\end{array}$ & $\begin{array}{c}\text { Mon } \\
\text { soon }\end{array}$ & $\begin{array}{c}\text { Post } \\
\text { monsoon }\end{array}$ & $\begin{array}{c}\text { Pre } \\
\text { monsoon }\end{array}$ & Average & $\begin{array}{c}\text { Remarks: } \\
\text { Permissible value } \\
\text { with reference to } \\
\text { WHO (75 mg/l ) }\end{array}$ \\
\hline 1 & S1 & 69 & 82 & 79 & 76.66 & Excessive \\
2 & S2 & 78 & 99 & 80 & 85.66 & Excessive \\
3 & S3 & 92 & 115 & 104 & 103.66 & Excessive \\
4 & S4 & 75 & 102 & 89 & 88.66 & Excessive \\
5 & S5 & 81 & 116 & 102 & 99.66 & Excessive \\
6 & S6 & 79 & 124 & 111 & 104.66 & Excessive \\
7 & S7 & 110 & 126 & 180 & 138.66 & Excessive \\
8 & S8 & 120 & 145 & 122 & 129.00 & Excessive \\
9 & S9 & 125 & 147 & 127 & 133.00 & Excessive \\
10 & S10 & 111 & 112 & 110 & 111.00 & Excessive \\
\hline
\end{tabular}

Fig. 13: Seasonal variation of Magnesium (Mg2+) $\mathrm{mg} / \mathrm{l}$ value with average and permissible value

\begin{tabular}{lcccccc}
\hline $\begin{array}{c}\text { SI. } \\
\text { No }\end{array}$ & $\begin{array}{c}\text { Pocation } \\
\text { Points }\end{array}$ & $\begin{array}{c}\text { Mon } \\
\text { soon }\end{array}$ & $\begin{array}{c}\text { Post } \\
\text { monsoon monsoon }\end{array}$ & $\begin{array}{c}\text { Pre } \\
\text { Average }\end{array}$ & $\begin{array}{c}\text { Remarks: } \\
\text { Permissible value } \\
\text { with reference to } \\
\text { WHO }(\mathbf{5 0} \mathbf{~ m g / l})\end{array}$ \\
\hline & & & & & & \\
1 & S1 & 180 & 169 & 132 & 160.33 & Excessive \\
2 & S2 & 176 & 158 & 127 & 153.66 & Excessive \\
3 & S3 & 200 & 190 & 140 & 176.66 & Excessive \\
4 & S4 & 182 & 173 & 144 & 166.33 & Excessive \\
5 & S5 & 170 & 156 & 123 & 149.66 & Excessive \\
6 & S6 & 162 & 149 & 120 & 143.66 & Excessive \\
7 & S7 & 158 & 151 & 129 & 146.00 & Excessive \\
8 & S8 & 151 & 142 & 131 & 141.33 & Excessive \\
9 & S9 & 150 & 142 & 131 & 141.00 & Excessive \\
10 & S10 & 295 & 282 & 138 & 238.32 & Excessive \\
\hline
\end{tabular}


level.

$\mathrm{NO}_{3}^{-}$

In the study area there is no significant change in nitrate concentration and the maximum nitrate was observed at sample station S-9 is 38.5 $\mathrm{mg} / \mathrm{l}$ in monsoon season and minimum was observed sample station S-5 in $22.1 \mathrm{mg} / \mathrm{l}$ in pre monsoon season (Fig. 2). The Nitrate range in all the stations is within the permissible limit i.e $50 \mathrm{mg} / \mathrm{l}$ (WHO) standard.

\section{CONCLUSION}

From the above study it is concluded that all the ten selected location of the Berhampur city does not meet all the standard values of parameters, It is observed that the location S-3, S-9 and S-10 have highest values of parameters except nitrate, magnesium, $\mathrm{pH}$, alkalinity .the highest value Of WQI .Therefore observed at S-3, S-9, and S-10 this three

Fig. 14: Seasonal variation of Nitrate (No3-) $\mathrm{mg} / \mathrm{l}$ value with average and permissible value

\begin{tabular}{lcccccc}
\hline $\begin{array}{c}\text { SI. } \\
\text { No }\end{array}$ & $\begin{array}{c}\text { Location } \\
\text { Points }\end{array}$ & $\begin{array}{c}\text { Mon } \\
\text { soon }\end{array}$ & $\begin{array}{c}\text { Post } \\
\text { monsoon }\end{array}$ & $\begin{array}{c}\text { Pre } \\
\text { monsoon }\end{array}$ & Average & $\begin{array}{c}\text { Remarks: } \\
\text { Permissible value } \\
\text { with reference to } \\
\text { WHO (50 mg/l ) }\end{array}$ \\
\hline 1 & S1 & 35.1 & 33.2 & 31.2 & 33.16 & Permissible \\
2 & S2 & 36.0 & 34.5 & 34.5 & 35.00 & Permissible \\
3 & S3 & 26.8 & 25.3 & 34.7 & 28.93 & Permissible \\
4 & S4 & 24.6 & 24.6 & 22.3 & 23.83 & Permissible \\
5 & S5 & 22.2 & 23.2 & 22.1 & 22.50 & Permissible \\
6 & S6 & 32.4 & 32.4 & 31.0 & 31.93 & Permissible \\
7 & S7 & 29.0 & 28.4 & 28.4 & 28.60 & Permissible \\
8 & S8 & 37.2 & 35.2 & 34.3 & 35.56 & Permissible \\
9 & S9 & 38.5 & 38.4 & 32.1 & 36.33 & Permissible \\
10 & S10 & 36.2 & 34.3 & 34.3 & 34.93 & Permissible \\
\hline
\end{tabular}

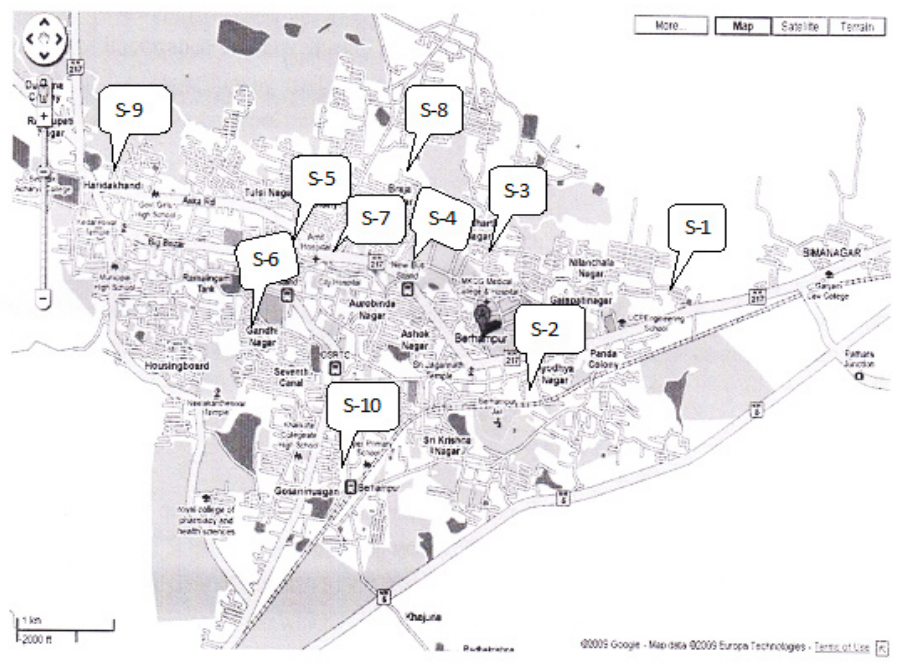

Fig. 1: Sampling location point along the Berhampur city 




Fig. 2: Seasonal variation of water quality parameters along Berhampur city 
location of ground water are not suitable for human consumption, for there the value of magnesium, calcium, and chloride are significantly inter related and indicate that the hard ness of water is permanent

season. in nature. So the ground water need some degree of treatment before consumption and the ground water needs to be protected from future contamination and the quality of ground water may be improved by the inflow of fresh water of good quality during rainy

\section{REFERENCE}

1. Adekunle, A.S. Effects of industrial effluent on quality of well water within ASa Dam Industrial Estate, Ilorin Nigeria. Nature and science: 7(1), (2009).

2. APHA, Standard methods for examination of water and waste water. American public Health Association Washington D.C. $19^{\text {th }}$ Edition, (2005).

3. BIS (Bureau of India standards) 10500. Indian standard drinking water. Specification. First revision. PP 1-8. (1991).

4. Chauhan, A., Pawar, M., and Lone, S.A., , Water quality status of Golden Key lake in clement town, Dehradun, Uttarakhand. J. Am. Sci. 611 :459-464(2010).

5. Horten, R.K., (1965), An Index number for rating water quality. J. Water Poll. Cont. Fed. 37(3):300-306.

6. Indian standard specification for drinking water IS: 10500, Bureau of Indian standard specification standards, New Delhi, (1998).

7. Kakati, S.S., and Sarma, H.P., Water quality index of drinking water of Lakhimpur district. Indian J. Environ. Prot. 27(5):425:428,(2007).

8. Pandey, sandeep K, Tiwari, S. Physico - chemical analysis of ground water of selected area of Ghazipur city. A case study nature and science, 7 (1). (2009).

9. Patel and Sing., Journal of Env. Pollution,(1998).

10. Sahu BK. Panda.RB, Sinha BK and Nayak Water quality Index of the river Brahamani at Rourkela Industrial Complex of Orissa. J. Eco-toxical. Environ. Moni. 1(3): 169:175, (1991).

11. Sinha D.K., Shilpi S. and Ritesh S. Water Quality Index for Ram Ganga River at Mordabad. Poll. Res. 23(3): 527-531, (2004).

12. Tiwari T.N., and Mishra M.A., A preliminary assignment of water quality index of major Indian rivers. Indian J Environ Prot., 5(4): $276-279$ (1985).

13. Trivedy, R.K., and Goel, P.K, Chemical and Biological methods for water pollution studies environmental publications, Karad, 1-112, (1984).

14. WHO (World Health organization) Guidelines for drinking water Quality. $2^{\text {nd }} \mathrm{Ed}$, , Vol. I.P. 188,(1993).

15. WHO, Guidelines for drinking water quality world Health organization, Geneva (1993)

16. WHO, International standard or drinking water. World Health organization, Geneva, 3rd Edn.:(1971). 